5. Tukova, I. (2003). Functionalization of instrumental genre models of the West European baroque in Ukrainian music of the second half of the twentieth century. Extended abstract of Ph.D. thesis. 17.00.03. Kyiv. [in Ukrainian]

6. Einstein, A. (1969). Mozart (A. Mendel and N. Broder Trans.). London: Oxford University Press.

7. Bertil van Boer. (2012). Historical Dictionary of Music of the Classical Period. Lanham, MD: Rowman \& Littlefield Publishers, Inc.

8. Fortune, N., Timms, C., Boyd, M., Krummacher, Fr., Tunley, D. (1980). Cantata. In: The New Grove Dictionary of Music and Musicians. 6th ed., vol. 3. (ed. by S. Sadie). London: Macmillan Publishers, p. 694-718.

9. Kenneth Jaffe. (2010). Solo Vocal Works on Jewish Themes: A Bibliography of Jewish Composers. Lanham, MD: Rowman \& Littlefield Publishers, Inc.

10. Melograni, P. (2006). Wolfgang Amadeus Mozart: A Biography (Lydia, G. Cochrane Trans.). Chicago: University of Chicago Press.

11. Otto Jahn. (1882). Life of Mozart. (P. D. Townsend, Trans). London: Novello Ever \& Co. Park Press.

12. Paul F. Rice. (2002). Solo Cantata in Eighteenth-Century Britain. (A Thematic Catalog). Detroit: Harmonie \& Francis

13. Talbot, M. (Eds.). (2009). Aspects of the Secular Cantata in Late Baroque Italy. (1st ed.). London: Taylor

14. Timms, C., Fortune, N., Boyd, M., Krummacher, Fr., Tunley, D., Goodall, J. R., José, J. (2001). Cantata. Grove Music Online. Retrieved from https://doi.org/10.1093/gmo/9781561592630.article.04748

Стаття надійшла до редакції 19.11.2018 p.

УДК 780.616.433.071.2.(7/8)“19”

\author{
Шадько Максим Олександрович, \\ аспірант, викладач кафедри концертмейстерської \\ майстерності Харківського національного \\ університету мистецтв імені І. П. Котляревського \\ shadkomaksym@gmail.com
}

\title{
НОВИЙ ПІДХІД ДО ВИРАЗОВИХ МОЖЛИВОСТЕЙ ФОРТЕПІАНО У ТВОРЧОСТІ АМЕРИКАНСЬКИХ КОМПОЗИТОРІВ ХХ СТОЛІТТЯ
}

Мета роботи пов'язана 3 розглядом техніко-виразових можливостей фортепіано в творчості американських композиторів-новаторів XX століття, висвітленням новітніх способів звуковидобування і зміни тембру та їх ролі у процесі розвитку художньої ідеї. Методологія дослідження полягає у застосуванні історикотеоретичного, структурно-функціонального та порівняльного методів, які дозволяють розкрити своєрідність підходів до фортепіано на сучасному етапі музичного мистецтва та композиційно-драматургічні особливості творів, написаних для перетвореного інструменту. Наукова новизна роботи визначається виявленням процесу еволюційних змін щодо трактування фортепіано американськими композиторами-новаторами минулого століття, що сприяє осмисленню спадкоємних зв'язків між індивідуальними підходами. Висновки. На підгрунті існуючих досліджень та власних аналітичних спостережень доведено, що Г. Кауелл, Дж. Кейдж та Дж. Крам розкрили нові можливості клавішного інструменту, що дозволило кожному з композиторів затвердити новий його підвид: «струнне фортепіано» Г. Кауелла передбачає активне задіяння гри на струнах, «підготовлене фортепіано» Дж. Кейджа - зміну тембру за рахунок немузичних предметів, а «розширене фортепіано» Дж. Крама - гармонійне об’єднання та максимальне збагачення попередніх винаходів в контексті авторської багатогранної художньої концепції. Названі митці поповнили музичну мову оригінальними новаціями та відкрили шлях для подальшого удосконалення піаністичної техніки.

Ключові слова: американські композитори-новатори ХХ століття, струнне фортепіано Г. Кауелла, підготовлене фортепіано Дж. Кейджа, розширене фортепіано Дж. Крама, нові способи гри на фортепіано.

Шадько Максим Александрович, аспирант, преподаватель кафедры кониертмейстерского мастерства Харьковского национального университета искусств имени И. П. Котляревского

Новый подход к выразительным возможностям фортепиано в творчестве американских композиторов XX века

Цель работы связана с рассмотрением технико-выразительных возможностей фортепиано в творчестве американских композиторов-новаторов XX века, освещением новейших способов звукоизвлечения и смены тембра, а также их роли в процессе развития художественной идеи. Методология исследования заключается в применении историко-теоретического, структурно-функционального и сравнительного методов, которые

(C) Шадько М. О., 2019 
позволяют раскрыть своеобразие подходов к фортепиано на современном этапе развития музыкального искусства и композиционно-драматургические особенности сочинений, написанных для преобразованного инструмента. Научная новизна работы определяется выявлением процесса эволюционных изменений трактовки фортепиано в творчестве американских композиторов-новаторов прошлого столетия, что способствует осмыслению наследственных связей между индивидуальными подходами. Выводы. На основе существующих исследований и собственных аналитических наблюдений доказано, что Г. Кауэлл, Дж. Кейдж и Дж. Крам раскрыли новые возможности клавишного инструмента, что позволило каждому из композиторов утвердить новый его подвид: «струнное фортепиано» Г. Кауэлла подразумевает активное задействование игры на струнах, «подготовленное фортепиано» Дж. Кейджа - изменение тембра за счет немузыкальных предметов, а «расширенное фортепиано» Дж. Крама - гармоничное объединение и максимальное обогащение предыдущих изобретений в контексте авторской многогранной художественной концепции. Названные творцы пополнили музыкальный язык оригинальными новациями и открыли путь для дальнейшего усовершенствования пианистической техники.

Ключевые слова: американские композиторы XX века, струнное фортепиано Г. Кауэлла, подготовленное фортепиано Дж. Кейджа, расширенное фортепиано Дж. Крама, новые способы игры на фортепиано.

\section{Shadko Maksym, postgraduate student in Kharkiv National University of Arts named after I. P. Kotlyarevsky the 20th Century \\ A New Approach to Piano Expressive Capabilities in the Creative Work of the American Composers of \\ The purpose of the article is related to the consideration of technical and expressive capabilities of a piano in} the creative work of innovative American composers of the 20th century; revealing of the newest ways of phonation and timbre changes as well as their role in artistic idea development. The methodology of the research is to apply historical and theoretical, structural and functional methods as well as the comparative method that allow revealing peculiarities of piano approaches at the present stage of musical art as well as compositional and dramatic peculiarities of works written for the instrument with a new way of sound. The scientific novelty of the work is determined by the discovery of evolutionary piano changes process interpreted by innovative American composers of the last century, which contributes to the understanding of successful relationships between individual approaches. Conclusions. Based on the existing researches and own analytical observations, it has been proved that H. Cowell, J. Cage and G. Crumb discovered new possibilities of keyboard instrument, which allowed each of the composers to approve its new version: H. Cowell's "string piano" involves active play on strings, J. Cage's "prepared piano" involves a change in timbre due to non-musical subjects, and G. Crumb's "extended piano" provides harmonious association and maximum enrichment of previous inventions in the context of authorial multifaceted artistic concept. The abovementioned artists enriched musical language with original innovations and opened the way for further improvement of piano technique.

Key words: innovative American composers of the 20th century, H. Cowell's string piano, J. Cage's prepared piano, G. Crumb's extended piano, new ways of piano playing.

Актуальність теми дослідження. Історія розвитку фортепіано охоплює понад три століття завдяки винаходу Бартоломео Крістофорі (1655-1731), який запропонував новий інструмент 3 ударно-молоточковою механікою. За цей значний час його конструкція, форма, звук та динаміка поступово змінювалися. У ХІХ столітті саме фортепіано стало своєрідним «голосом епохи». Композитори-романтики, які були ще й блискучими виконавцями, довели техніко-виразові можливості інструменту майже до межі, що обумовило нові пошуки у ХХ столітті. Більшість композиторів займалися кардинальним оновленням музичної мови, зберігаючи при цьому традиційний погляд на використання фортепіанної механіки. Інші - вирішили піти шляхом розширення фортепіанної фоніки, задіюючи такі конструктивні складові, як струни, поперечні балки та власне корпус роялю, використовуючи деякі зовнішні предмети для зміни характеристики звучання. Першість у цьому процесі належить американським композиторам Г. Кауеллу, Дж. Кейджу та Дж. Краму, які виявили неабияку винахідливість, по-різному розкривши раніше незадіяний потенціал фортепіано. Не дивлячись на те, що названі композитори вже давно широко відомі у всьому світі, їх творчість ще й досі не знайшла достатнього висвітлення у вітчизняній науковій літературі.

Аналіз досліджень i публікацій. Питання експериментів 3 фортепіано у XX столітті найчастіше подаються дослідниками в контексті характеристики творчості того чи іншого композитора або ж панорамного огляду даного періоду історії музики, зокрема американської. Серед значних монографій слід назвати праці О. Григоренко [1], О. Івашкіна [2], В. Конен [4], О. Манулкіної [5], М. Переверзєвої [7], С. Сігіди [9], Г. Шнеєрсона [10].

Мета дослідження - простежити еволюцію поглядів американських композиторів-новаторів XX століття щодо трактування можливостей фортепіано з виявленням взаємозв'язку змістової сторони творів з новими тембро-фонічними уявленнями і способами звуковидобування. 
Виклад основного матеріалу. Фортепіано можна віднести до найстаріших інструментів музичної Європи. Воно пройшло шлях свого розвитку від клавіру, під яким у XVII-XVIII століттях розумілося сімейство різноманітних клавішно-струнних інструментів, до сучасного роялю, що має діапазон більше семи октав. Радикальний погляд на можливості цього інструменту виник у контексті технологічних новацій сучасної музики. Руйнування тональності спричинило пошук нових способів організації дванадцятитонового звукоряду та прагнення вийти за межі темперованого ладу. На тлі цих загальних процесів деякі композитори зосередилися на розширенні можливостей фортепіано, залучаючи до процесу гри всі складові його конструкції. Піонером у цьому питанні став Генрі Кауелл (Henry Cowell, 1897-1965), який був значною фігурою культурного життя США початку ХХ століття. Свої новації Г. Кауелл іменував «струнне фортепіано», оскільки використовував різноманітні способи гри на струнах (pizzicato та glissando, задіяння сурдин та інших предметів), що змінювали забарвлення звуку. Яскравим прикладом «струнного фортепіано» є п’єса «Еолова арфа» («Aeolian Harp»), створена у 1923 році. У цій мініатюрі, записаній на одному нотному стані, розкривається звукозображальний потенціал клавішно-струнно-ударного інструменту та знаходить ідеальне втілення заявлений у назві художній образ. Відомо, що еолова арфа отримала свою назву на честь давньогрецького бога вітрів Еола. Ї̈і конструкція передбачала наявність дерев'яного резонатора та натягнутих від нього струн різного діаметру, налаштованих на одну висоту. Звуковидобування вироблялося вітром, що приводив струни у рух, а музика складалася 3 обертонів одного тону $[6,1047]$.

Як же вирішує поставлене завдання Г. Кауелл? П'єса ділиться на чотири речення, останнє 3 котрих точно повторює матеріал першого, створюючи репризу тричастинної форми. Композитор обіграє вертикаль та горизонталь: це дає йому можливість задіяти різні прийоми гри всередині корпусу. На відміну від непередбачуваності звукового результату еолової арфи, у п’єсі автор чітко прописує свої уявлення. Як і при традиційній грі на фортепіано, тут задіяні обидві руки, що візуально демонструє нову трактовку інструменту. Рольова функція лівої руки зводиться до беззвучного натиснення акордів визначеної гармонічної послідовності, які отримують звукову плоть завдяки висхідним та низхідним glissando по струнам правою рукою. Звертає на себе увагу простота та вишуканість акордових поєднань, адже, затверджуючи панування мажорного тризвуку як символу краси, чистоти, піднесення, автор ускладнює його при низхідному русі секундовими сполученнями, бінарною терцією, грою світлотіні через зміну опорних тонів вертикалі. Загострення-руйнування гармонії врівноважується розкладеним мажорним тризвуком, виконаним на струнах штрихом pizzicato та викладеним у вигляді quasi-обертонової шкали. Г. Кауелл наприкінці першого та четвертого речень вводить виразову деталь: неочікувана восьма на медіанті тризвуку подібна легкому вітерцю, що нагадує про себе, як про головного «виконавця» на еоловій арфі.

Експерименти Г. Кауелла надихнули багатьох композиторів, першість серед яких займає Дж. Кейдж (John Cage, 1912-1992). Загальновідомим є безпосередній зв'язок двох композиторів, який починався у форматі «учитель-учень» та згодом переріс у дружні відносини. Як асистент людина, котра натискала на педаль, - Дж. Кейдж приймав участь у дослідах зі «струнним фортепіано». Композитор підхоплює ці ідеї та включає партію «струнного фортепіано» у свою «Другу конструкцію» для ансамблю ударних інструментів, де піаніст має притискати струни, грати glissando на них металічним циліндром та калаталом від гонгу. Не обмежуючись лише розвитком чужих концепцій, Дж. Кейдж скоро винаходить власний підхід, який увійшов у історію музики під назвою «підготовлене фортепіано» («prepared piano»). Цим терміном іменується інструмент, тембр якого змінюється завдяки розміщенню у корпусі та між струнами різноманітних побутових предметів, зокрема болтів з гайками, шурупів, фетру, шматків пластику, пористої гуми тощо. Як відзначає сам композитор, ці дії призводять до нівелювання притаманних інструменту характеристик та наділяють його новими «які навіть не нагадують фортепіано» $[11,3]$. Дж. Кейдж пише низку творів для підготовленого фортепіано, одним з яких постає «Небезпечна ніч» (1944). Жанрове позначення сюїта - підкреслює орієнтацію композитора-авангардиста на сформовану традицію. Цикл включає у себе шість контрастних за стилістичним виглядом п'єс, остання з яких виконує функцію фіналу, про що свідчить їі масштаб, синтезування деяких фактурних та ритмічних формул. Між тим, Дж. Кейдж уникає темброфонічних паралелей, трактуючи фортепіано як ударний інструмент. Завдяки різним немузичним способам зміни звуку, автор створює ілюзію участі у дійстві цілого ансамблю.

Візуально нотний текст заснований на типовій лексиці та характерних фортепіанних прийомах. Достатньо вказати на регістрові зіставлення, остінатні ритмогрупи і формули, гротескові елементи у виникаючих мелодичних фразах, різноманітну та деталізовану динаміку. Кожна 3 п’єс циклу спирається на звичайні логічні закономірності. Основні принципи побудови розглянемо на 
прикладі першого номеру, де ключовим елементом є ряд з п’яти звуків- $d, f, f i s, g, a s$, комбінація яких піддається фактурно-ритмічному варіюванню: чергуються поступовий рух та остінатні повтори, гармонічна вертикаль та пуантилістичний розкид; постійно змінюється ритмічне групування, безперервно відбувається своєрідна гра паузами. Закладений у початковий звукоряд хроматизм дозволяє оперувати ним не тільки у висхідному, низхідному русі та оспівуванні, але й зібрати його у кластерну або різку дисонуючу вертикаль, що також є одним з проявів варіювання. П'єса складається 3 шести секцій, відокремлених одна від одної двома тактовими рисками. Перші три експонують основні ідеї п'єси: 1. довгої консонуючої вертикалі, заснованої на великій сексті, та хроматичної мелодії з форшлагами, яка в останніх трьох тактах складається у кластер; 2. співставлення консонуючої вертикалі та дисонуючого їй fis, який багаторазово повторюється та поступово переростає у хроматичний хід; 3 . консонуючої вертикалі $f$ - $d$ - $f$ із колиханням восьмих у лівій руці та остинатних ударів у правій, що доповнюється хвилеподібною динамікою. Наступна секція розробляє усі заявлені раніше ідеї та окремі їх елементи. Вони перемішуються, віддзеркалюються, зіставляються між собою. Саме ця секція є об'ємнішою за попередні. П'ята секція постає різними інтонаційними варіантами хроматичного ходу основного звукоряду у мелодичній лінії. Гармонічна вертикаль тут складається $3 f$ та $f i s$, які утворюють велику септиму. Остання секція витікає 3 попередньої та повертає початкову структуру. В останніх кульмінаційних тактах затверджується первинний звукоряд [8, 40-42].

Проте ідея «підготовки» руйнує усталений тісний взаємозв'язок видимого-читаного (нотний текст) і відтворюваного. Досить простий та нехитрий спосіб запису «Небезпечної ночі» провокує уяву на тотожний йому звуковий результат, однак тотальна зміна тембру задіяних звуків, застосована 3 надзвичайною винахідливістю, розфарбовує музику, робить ії дивовижно різноманітною. Можна почути крик невидимого нічного птаха, шелест дерев, ледве вловимі скрипи, неочікувані завмирання віддалених шерехів 3 наступним вторгненням химерних невідомих звуків. Така палітра асоціацій виникає завдяки наявності унікального соноряду (термін М. Переверзєвої), який уявляє собою «комплекс спеціально створених елементів: шумів та колористичних фігур, що відрізняються за тембровими властивостями» [7,180]. У «Небезпечній ночі» він складається 3 двадцяти-шести «сонорних одиниць» $[7,189]$. Пояснювальна таблиця підготовки, подана перед нотним текстом, налічує до десяти різних металевих та м'яких предметів, форми й розміри яких детально прописані. Інколи навіть один звук препарується одразу двома різними матеріалами [8, 38-39]. У цьому сенсі «Небезпечна ніч» $є$ одним 3 показових прикладів зрілого осмислення власних новацій у творчості Дж. Кейджа, де підготовка постає визначальним фактором драматургічного розвитку.

Ретроспективний погляд на діяльність Г. Кауэлла та Дж. Кейджа дозволяє говорити про визначення ними багатьох векторів подальшого розвитку музики. Одним 3 найяскравіших послідовників фортепіанних новацій виявився Джордж Крам (George Crumb, 1929 р. н.). Поєднуючи знахідки своїх попередників, а потім і значно доповнюючи їх, композитор створює своєрідний та унікальний підхід до трактування фортепіано, що отримав надалі назву "розширене фортепіано» («extented piano»). Такий інструмент включає у себе як різноманітні способи гри на струнах (glissando, pizzicato, видобування гармонік, приглушення звуків тощо), так і зміну його тембру за допомогою різних музичних та немузичних предметів (паперу, склянок, металевого ланцюжку, наперстку, щіточки для ударних інструментів тощо); нерідко підключаються удари по корпусу та поперечним балкам роялю; передбачається активне використання середньої sostenuto педалі, принцип роботи якої полягає у подовженні визначених звуків або співзвуч. Для більшого ефекту від усіх цих прийомів звук часто посилюється через мікрофон, що відображається на титульних сторінках партитур написом «amplified piano». Дж. Крама ніколи не цікавив експеримент у чистому вигляді, а скоріше навпаки - усі новації нерозривно пов'язані з драматургічним наповненням творів. Художні ідеї композитора - своєрідний всесвіт з філософських, релігійних, міфологічних, астрологічних, літературних, історичних, містичних та музичних уявлень. Саме їх автор реалізує у своїй творчості за допомогою нетрадиційних способів гри. Дж. Крам активно залучає засоби візуалізації та театралізації художнього задуму. Перший виражається за допомогою авторської графічної нотації, другий перетворює піаніста у актора, котрий має кричати, шепотіти, шипіти, проговорювати різноманітні звуки, співати та свистіти під час виконання. Важливим для нас $є$ той факт, що саме фортепіано виявилося для Дж. Крама універсальним інструментом, здатним ретранслювати усі його генеральні ідеї. Про це свідчить як кількість власне фортепіанних творів, так і включення роялю до складу більшості партитур для різних складів [12].

Не дивлячись на явне наслідування новацій своїх співвітчизників, Дж. Крам стверджував, що створюючи свої «П'ять п’єс» - перший твір для «розширеного фортепіано» - мав лише невеличкі 
теоретичні знання, але не мав слухового уявлення ні про «струнне», ні про «підготовлене» фортепіано, а познайомився й оцінив їх пізніше $[9,439 ; 3,6]$. Цей цикл був створений у 1962 році. Вже тут ми бачимо ознаки, що стали своєрідним «обличчям» партитур Дж. Крама. Йдеться про так звані «performance notes», в яких автор досить детально пояснює особливості своїх умовних позначок, нотації та способів звуковидобування. Примітки до виконання «П'яти п'єс» $€$ важливими у процесі простеження еволюції творчого почерку композитора, бо вони містять ідеї, що активно розвиватимуться надалі. До них відносяться, наприклад, чітке розгалуження прийому pizzicato на pizzicato finger tip (подушечкою пальця) та pizzicato finger nail (нігтем); подання таблиці звуків, що потребують спеціальних відміток для виконання запропонованих ефектів, особливо гармонік, та пояснень найліпшого способу їх реалізації. Цікавими є застосування і опис ефектів «металевого вібрато» за допомогою скріплення для паперів та вібрації подушечкою пальця на струні $[8,53]$. За думкою О. Івашкіна та А. Хітрука, основним завданням «П’яти п’єс» є своєрідне декларування композитором свого власного бачення фортепіано: «елементи стилю, що нагадують про вебернівську економію засобів, пуантилізм, в поєднанні з віяннями фольклору Західної Вірджинії (батьківщини композитора), а також спеціальні тембральні ефекти $<\ldots>$, - усе це в підсумку народжує відчуття нового інструменту <..>» [3, с. 6]. На нашу думку, саме цим пояснюється відсутність у творі характерної крамівської програмності. На їі остаточну кристалізацію композитор витратив близько десяти років, адже саме цей проміжок часу відділяє «П'ять п’єс» від наступного масштабного твору для фортепіано. Поступове ускладнення драматургічних ідей Дж. Крама віддзеркалюється у назвах творів, які з часом ставали більш вишуканими та охоплювали все більше тем і явищ [12], що безумовно вимагало певного узагальнення. Подібні умови стали підгрунтям для появи «Макрокосмосу», що повно відображає драматургічні вектори творчості композитора, репрезентує його багатий світогляд й усі виразові можливості «розширеного фортепіано».

На відміну від ранніх «П'яти п'єс» номери кожного 3 чотирьох томів грандіозного циклу мають програмну назву, часом подвійну. Перші два томи (1972-1973) адресовані для солюючому електронно-посиленому фортепіано та позначені підзаголовком «Дванадцять п’єс-фантазій за знаками зодіаку», тому до основної назви кожної мініатюри додано ще й найменування та позначка певного знаку зодіакального кола. Інколи ці два образних плани знаходяться у консенсусі, а інколи протиставляються один одному. Композитор ділить циклічну форму на три великі частини, кожна 3 яких утворена 3 чотирьох п’єс. Кожна четверта $-\epsilon$ п’єсою-символом, що графічно зображує закладену у назві ідею: «Crucifixus» (1 т., № 4) постає у вигляді хреста, «Спіральна галактика» (1 т., № 12) - спіралі, «Сонця-близнюки (Двійник 3 вічності)» (2 т., № 4) - двох однакових кіл, «Agnus Dei» (2 т., № 12) - знаку миру. Деякі назви вказують на спорідненість перших двох томів «Макрокосмосу». Так, «Доісторичні звуки (Генезис I)» (1 т., № 1) пов’язані з «Ранковою музикою (Генезис II)» (2 т., № 1), «Нічне заклинання І» (1 т., № 6) 3 «Примарним ноктюрном: для друїдів Стоунхенджу (Нічне заклинання II)» (2 т., № 5). Кількість задіяних у творі можливостей «розширеного фортепіано» значно збагатилася: ширше прописані «performance notes» 3 доповненням видів pizzicato за тембровим показником та більш детальними роз'ясненнями як потрібного звукового результату, так і способів його досягнення. Показовими у цьому зв'язку є залучення не одного, а двох видів гармонік - другого та п’ятого обертонів. Також додані удари по корпусу інструменту та використання більшої кількості немузичних предметів (металевий ланцюжок, наперсток, склянки, папір тощо). Але не одна з багатьох використаних технік гри не $\epsilon$ ізольованою від драматургічного задуму. Зокрема, багато різноманітних «спецефектів» - pizzicato нігтем та подушечкою пальця, скреботіння по металевій обмотці басових струн, martellato на струнах за допомогою наперстка тощо - застосовано для створення містичної атмосфери «Примарного (Фантомного) гондольєра» (1 т., № 5), а у «Музиці тіней (для Еолової арфи)» (1 т., № 7) стародавній інструмент імітується круговими glissando, що озвучують беззвучні кластерні вертикалі. На відміну від «П'яти п'єс», у «Макрокосмосі» важливою драматургічною складовою стає голосовий апарат піаніста. Наприклад, для підтримання саспенсу «Crucifixus» (1 т., № 4) виконавець у визначений час має дуже голосно викрикнути «Criste!»; свист у «Нічному заклятті I» (1 т., № 6) імітує «спів нічного птаха» (Дж. Крам), а у «Космічному вітрі» (2 т., № 9) звук вітру створюється завдяки прийому «беззвучного співу» (Дж. Крам). Наведені факти підкріплюють думку, що «розширене фортепіано» здатне висвітлити багатоскладові концепції Дж. Крама та донести до слухачів його філософсько-естетичні погляди.

Наукова новизна. Вперше в українському музикознавстві окреслюються вектори розвитку уявлень про виразові можливості фортепіано у творчості американських композиторів-новаторів XX століття. 
Висновки. Фортепіанна музика XX століття розвивалася у багатьох, нерідко полярних напрямках. Новаціями відзначена творчість американських композиторів - Г. Кауелла, Дж. Кейджа та Дж. Крама, які, кожен зі свого боку, значно збагатили арсенал техніко-виразових можливостей інструменту шляхом створення та використання нових прийомів гри на ньому. 3 одного боку, визначним у цьому процесі стало переосмислення функцій механічних складових (струн, поперечних балок, корпусу) та включення їх у ігровий процес, з іншого - спроба підміни природного звучання фортепіано завдяки використанню деяких побутових предметів. Панорамний огляд творчості трьох визнаних новаторів дозволив висвітлити три різні підходи до трактування інструменту, які не позбавлені спадкоємних зв'язків. На прикладі конкретних творів виявлено нерозривність зв'язку драматургічного задуму із винайденими способами звуковидобування. Доведено, що саме завдяки їм відбувається ретрансляція художніх концепцій композиторів.

\section{Jimepamypa}

1. Григоренко Е. Джон Кейдж: творчество. К. : Муз. Україна, 2012. 228 с.

2. Ивашкин А. Чарльз Айвз и музыка XX века. М. : Сов. композитор, 1991. 464 с.

3. Ивашкин А., Хитрук А. В поисках традиций. О фортепианной музыке США ХХ века. Пьесы американских композиторов XX века для фортепиано. М. : Музыка, 1991. С. 2-6.

4. Конен В. Пути американской музыки : очерки по истории муз. культуры США, Изд. 3-е, переработанное. М. : Сов. композитор, 1977. 446 с.

5. Манулкина О. От Айвза до Адамса: американская музыка XX века. СПб. : Изд. Ивана Ламбаха, 2010.784 с., ил.

6. Музыкальный словарь Гроува / пер. с англ., ред. и доп. Л. О. Акопяна. М. : Практика, 2001. 1095 с. 333 с., ил.,нот.

7. Переверзева М. В. Джон Кейдж: жизнь, творчество, эстетика : монография. М. : РУСАКИ, 2006.

8. Пьесы американских композиторов ХХ века для фортепиано / сост. А. Хитрук. М. : Музыка, 1991. $80 \mathrm{c}$.

9. Сигида С. Ю. Музыкальная культура США конца XVIII - первой половины XX века. Становление национальной идентичности : Очерки. М. : Композитор, 2012. 504 с.

10. Шнеерсон Г. Портреты американских композиторов. М. : Музыка, 1977. 232 с.

11. Cage J. Amores : Piano and percussion. New York [etc.] : C. F. Peters, 1945?. 16 p.

12. The Official George Crumb Website. URL : http://www.georgecrumb.net/ (дата звернення: 21.11.2018)

\section{References}

1. Grigorenko Ye. (2012). John Cage: creation. Kiev: Muz. Ukrajina [in Russian].

2. Ivashkin A. (1991). Charles Ives and music of XX century. Moscow: Sov. Kompozitor [in Russian].

3. Ivashkin A., Khitruk A. (1991). In search of tradition. About USA's piano music of XX century. Pieces by American composers of XX century for piano (pp. 2-6). Moskow: Muzyika [in Russian].

4. Konen V. (1977). Ways of American music: Essays about history of USA's musical culture. Moskow: Sov. Kompozitor [in Russian].

5. Manulkina O. (2010). From Ives to Adams: American music of XX century. St Peterburg: Izdatelstvo Ivana Lambakha [in Russian].

6. Grouv's musical dictionary (2001). Moskow: Praktika [in Russian].

Russian].

7. Pereverzeva M. V. (2006). John Cage: life, creation, esthetics: monograph. Moskow: RUSAKI [in

8. Pieces by American composers of XX century for piano (1991). Score. Moskow: Muzyika [in Russian].

9. Sigida S. Yu. (2012). USA's musical culture from the end of the XVIII to first half of the XX centure. Formation of national identity: Essays. Moskow: Kompozitor [in Russian].

10. Shneerson G. (1997). Portraits of American composers. Moskow: Muzyika [in Russian].

11. Cage J. (1945). Amores: Piano and percussion. Score. New York [etc.]: C. F. Peters [in English].

12. The Official George Crumb Website. Retrieved from: http://www.georgecrumb.net/ [in English].

Стаття надійшла до редакиії 07.12.2018 p. 